\title{
WATER-ETHANOL SEPARATION BY PERVAPORATION THROUGH SILK FIBROIN MEMBRANES
}

\author{
By Toshihiro Hirotsu*1, Shigeru Nakajima ${ }^{* 2}$, Aio Kitamura ${ }^{* 3}$, \\ Kensaku Mizoguchi ${ }^{* 1}$, and Yoshio Suda ${ }^{* 1}$ \\ *1 (Research Institute for Polymers and Textiles, \\ 1-1-4, Higashi, Tsukuba, Ibaraki 305, Japan) \\ *2 (Tokyo Metropolitan Institute of Textiles, \\ 3-15-5, Honjo, Sumida, Tokyo 130, Japan) \\ $\cdot 3$ (Tokyo University of Agriculture and Technology, \\ 2-24-16, Naka, Koganei, Tokyo 184, Japan)
}

\begin{abstract}
Silk fibroin membranes which were made insoluble by the treatments in saturated water vapor, in ethanol or in 50\% ethanol were investigated for water-ethanol permseparation by pervaporation. Permseparation became effective for the feeds with ethanol concentration ranging up to $90 \%$ when the membrane thickness was more than $20 \mu \mathrm{m}$. The permselectivity was somewhat greater with the membranes treated in water vapor than those treated in ethanolic solutions. Activation energy for permeation obtained from the Arrhenius plots was between 5 and $8 \mathrm{kcal} / \mathrm{mole}$. Separation factor for water was slightly smaller in the higher temperature range, and was correlated with the higher flux in the region.
\end{abstract}

\section{Introduction}

Silk fibroin is a natural polypeptide composed mainly of glycine (more than $40 \%$ ), alanine (about $30 \%$ ) and serine (more than $10 \%$ ), and is one of the most popular natural fibers. Much study on the structure and properties has been undertaken for a long time ${ }^{11}$, and attention has also been given to its application besides the use for wear. Silk fibroin is originally insoluble in usual state, but can be dissolved in aqueous solutions of some inorganic salts like $\mathrm{LiBr}$, which lead the hydration to break the hydrogen bonds between the amides on the fibroin chains. From the desalted solution by dialysis, films can be obtained by casting. Although the fresh film is soluble, it turns insoluble by some treatments with water vapor or with solvents like alcohols. Thus, the wider range of application of silk fibroin is expected. In fact, such insoluble fibroin has been applied to immobilization of enzymes ${ }^{2)}$. In addition, the permeation should be interesting, since much portion of the amorphous region of silk fibroin is composed of bulky side chains ${ }^{3)}$. Minoura et al. have recently reported the $\mathrm{O}_{2}$-permeation behaviors through the swollen fibroin membranes ${ }^{4}$.

By the way, many efforts have been underway to find the effective water-ethanol permselective membranes. In order to enhance the water permseparation from water-ethanol mixtures, the membrane must be more hydrophilic to attract water preferentially. Since silk fibroin contains hydrophilic polyamide structures, it should be interesting to see the water permselectivity through the membrane. We have therefore investigated the permseparation behaviors of water through the silk fibroin membranes, and have already reported the possibility as a rapid communication ${ }^{5)}$.

In this paper, we would like to report the water permselective behaviors through the silk fibroin membranes further investigated after that ${ }^{5)}$ with respect to various factors such as the membrane 
condition, temperature during pervaporation, and so on.

\section{Experimentals}

\subsection{Preparation of Silk Fibroin Membranes}

$21 \mathrm{~g}$ of degummed silk fiber was dissolved in $900 \mathrm{~mL}$ of $\mathrm{LiBr}$ aqueous solution $(9.3 \mathrm{~mol} / \mathrm{L})$ on standing overnight at room temperature. The solution was then warmed at $40^{\circ} \mathrm{C}$ for one hour to complete the dissolution. The fibroin solution was allowed to dialysis using cerophane film to remove $\mathrm{LiBr}$. The completion of desalting was confirmed with silver nitrate. The desalted silk fibroin solution was casted on a plastic plate and dried. Thus the membranes with approximate thickness $10,20,50,75$ and $110 \mu \mathrm{m}$ were obtained by changing the amount of casting solution. The dried fibroin membranes were treated with $100 \%$ ethanol and $50 \%$ aqueous ethanol as well as with saturated water vapor at room temperature for 24 hours, and were made insoluble.

\subsection{Pervaporation}

Water-ethanol separation was carried out with pervaporation. The details of this procedure have been described elsewhere ${ }^{6}$. A sheet of the membrane with $47 \mathrm{~mm}$-diameter was fixed to a cell holder, and aqueous ethanol were put in it. The other face of the membrane was evacuated at higher than $10 \mathrm{~Pa}$ in blank experiments.

The permeation rate or the flux $\left(Q, \mathrm{~kg} / \mathrm{m}^{2} \mathrm{~h}\right)$ was obtained by weighing the amount of permeates collected in a cold trap. Concentrations of water and ethanol of both feeds and permeates were measured by a gas chromatography.

Permselectivity was evaluated by separation factor $\left(\alpha_{\mathrm{EtOH}}^{\text {water }}\right)$, which was calculated from the following equation;

$$
\alpha_{\mathrm{EtOH}}^{\text {water }}=\left(X_{\text {water }} / X_{\mathrm{EtOH}}\right) /\left(Y_{\text {water }} / Y_{\text {EtOH }}\right)
$$

where $X_{\text {water }}$ and $X_{\mathrm{EtOH}}$ were the concentrations of water and ethanol in permeate respectively, and $Y_{\text {water }}$ and $Y_{\mathrm{EtOH}}$ were those in feed. The higher value of $\alpha$ naturally implies the higher water permselectivity.

The experimentals were carried out usually at $40^{\circ} \mathrm{C}$, and also in the range from $30^{\circ} \mathrm{C}$ to $50^{\circ} \mathrm{C}$ to investigate the temperature dependence. Activation energies of permeation were determined from the Arrhenius plots.

\section{Results and Discussion}

\subsection{Water Permselectivity}

Figures 1 and 2 show the dependence of pervaporation on the feed ethanol concentration, respectively, for the 50 and $75 \mu \mathrm{m}$ thickness membranes of silk fibroin being made insoluble by the treatments in ethanol $(50 \%, 100 \%)$ and in saturated water vapor. Ethanol concentration in permeate was generally lower than that in feed throughout the concentration range, and the water permselectivity was suggested in these membranes. The ethanol concentration in permeate was always lower when the membranes treated in water vapor were used. Flux generally decreased as the ethanol concentration in feed increased, and such permeation behavior is usual for the water-permselective membranes.

Permselectivity for water was presented with separation factor, and the dependence on the feed ethanol concentration was obtained. The results are shown in Figure 3, respectively for the membranes with various thicknesses. Separation factor was naturally dependent on the preparation of the

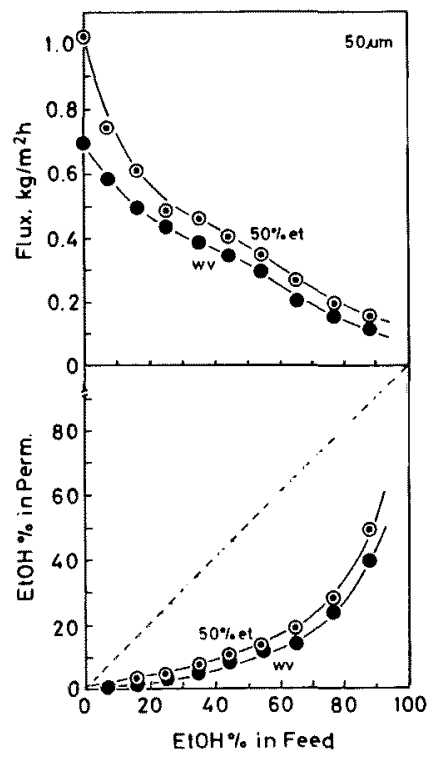

Fig. 1. Dependence of flux and separation by pervaporation at $40^{\circ} \mathrm{C}$ on the ethanol concentration in feed for the $50 \mu \mathrm{m}$-thickness fibroin membranes, respectively treated in $50 \%$ ethanol (50\%et) and in saturated water vapor (wv). 


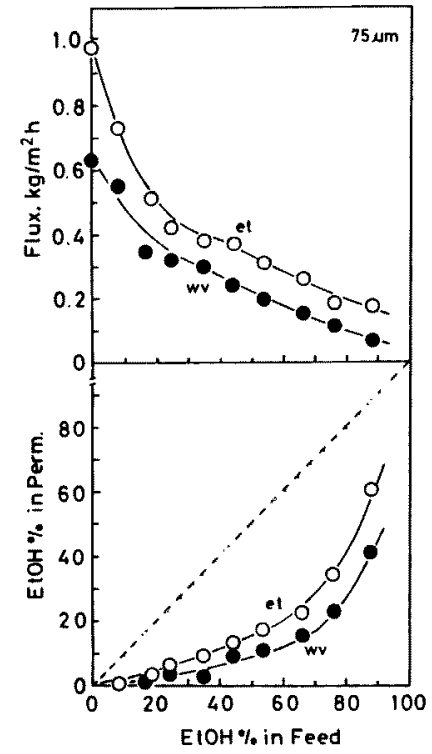

Fig. 2. Dependence of flux and separation by pervaporation at $40^{\circ} \mathrm{C}$ on the ethanol concentration in feed for the $75 \mu \mathrm{m}$-thickness fibroin membranes, respectively treated in $100 \%$ ethanol (et) and in saturated water vapor (wv).

membrane, and the higher values were obtained with the membranes being treated in water vapor.

Maximum of separation factor generally appears at around $60-70 \%$ ethanol in feed in usual waterpermselective membranes, while the behaviors are somewhat different in these fibroin membranes. The higher values were obtained in both side of water-rich and ethanol-rich solutions. The reason for such behaviors observed in silk fibroin mem-

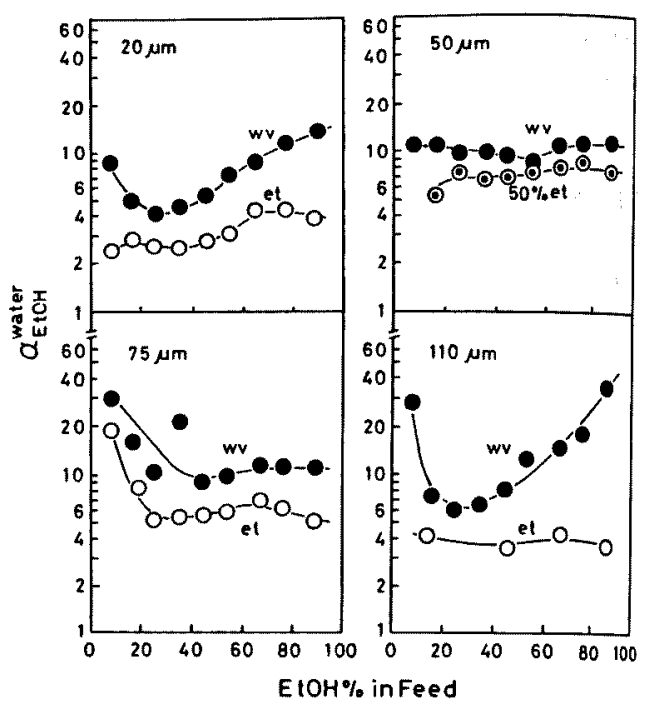

Fig. 3. Dependence of separation factor for water on the ethanol concentration in feed for the fibroin membranes.

branes can not be given at present exactly, but the unusual behaviors may result from some morphological changes of the membrane due to contact with feeds.

When fibroin membranes were made insoluble in aqueous ethanol with different concentrations, the $\alpha$-type and the $\beta$-rype amide structures were observed at $1650 \mathrm{~cm}^{-1}$ and $1630 \mathrm{~cm}^{-1}$ in infrared spectra, respectively ${ }^{7,8)}$. The absorption peak was not observed at $1630 \mathrm{~cm}^{-1}$ practically in the original membrane, and the peak depth according to this absorption increased with increasing the concentration of ethanol used for treatments as

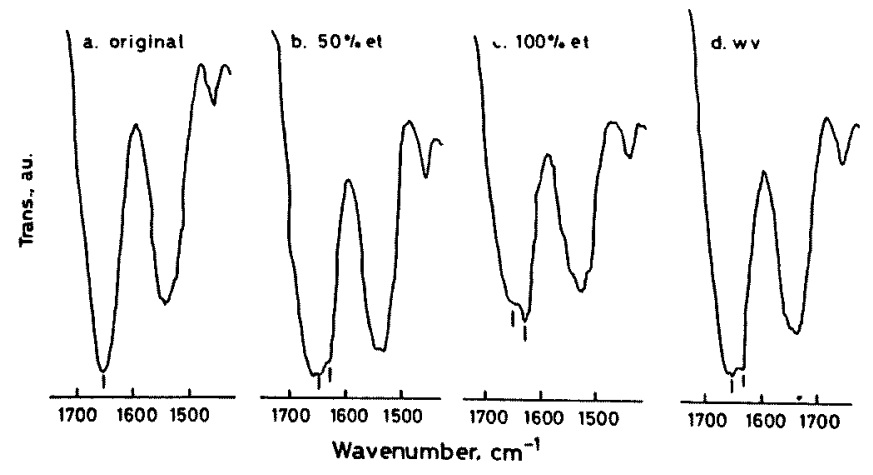

Fig. 4. Infrared spectra of the silk fibroin membranes; original (a), treated in $50 \%$ ethanol (b), in $100 \%$ ethanol (c), and in saturated water vapor (d). 
shown in Figure 4. The material permeation takes place naturally in the amorphous region. Although the changes observed in infrared spectra are only for the amide forms, these morphology changes might induce the changes in the amorphous region to affect the permseparation behaviors. Further investigation is however necessary for proving this assumptions.

The fibroin membranes showed water-permseparation ability by pervaporation, and the separation factor reached more than 10 as far as investigated in this study.

\subsection{Membrane Thickness Dependence}

As mentioned above, the permseparation was dependent on the state of membranes. Then the dependence on the membrane thickness was investigated. Figures 5 and 6 show the dependences of flux and separation factor, respectively, for the feeds with approximate 20, 50, 70 and $90 \%$ ethanols. Flux decreased from about $5 \mathrm{~kg} / \mathrm{m}^{2} \mathrm{~h}$ to $0.1 \mathrm{~kg} / \mathrm{m}^{2} \mathrm{~h}$ with increasing the thickness. When a $10 \mu \mathrm{m}$-thickness membrane was used, flux was abnormally high and the permseparation did not take place practically. This suggests that some defects are formed on the membrane during pervaporation or during the preparation of membranes.

Separation factor became larger as the membrane thickness increased, and this was closely related to

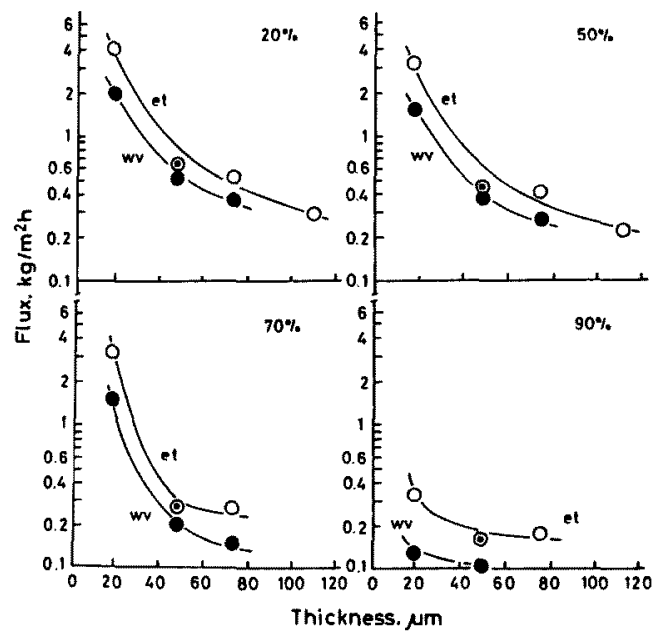

Fig. 5. Dependence of flux on the membrane thickness of silk fibroin membranes respectively for the feeds with about $20,50,70$, and $90 \%$ ethanol concentrations.

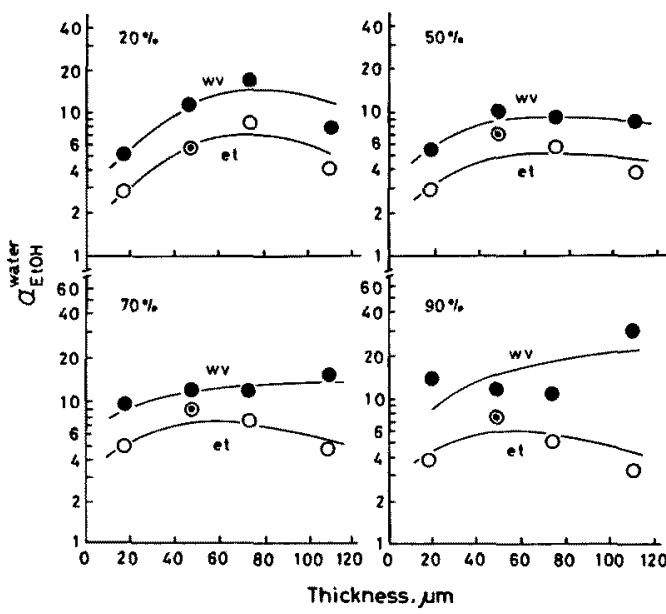

Fig. 6. Dependence of separation factor for water on the membrane thickness of silk fibroin.

the decrease of flux. As pointed out before, the value of separation factor was greater for the membranes treated in water vapor. It also should be noticed that the values of separation factor for the membrane treated in $50 \%$ ethanol was rather similar to that for the membrane treated in water vapor. This is possibly correlated with the structure as observed in infrared spectra; in other words, the peak shapes according to the $\beta$-form at $1630 \mathrm{~cm}^{-1}$ are similar to each othe as shown in Figure 4.

\subsection{Temperature Dependence}

Pervaporation was further carried out with some membranes in the temperature range between $30^{\circ} \mathrm{C}$ and $50^{\circ} \mathrm{C}$. Figures 7 and 8 show the Arrhenius plots of the permeation rates for the $50 \mu$ m-thickness membranes being made insoluble with $50 \%$ ethanol and with water-vapor, respectively. Flux naturally increased as the temperature increased. It has been reported that there existed some transition temperatures for dye diffusion in silk fibroin ${ }^{9}$, and that the transition was observed at around $35^{\circ} \mathrm{C}$ for the oxygen permeation through the swollen membranes ${ }^{4}$. However in the pervaporation of water-ethanol mixtures, such transition was not clearly observed in the temperature range investigated in this study.

Activation energies were obtained from the slopes using the equation $Q=Q_{0} \ln \left(-\Delta E_{\mathrm{a}} / R T\right)$, where $Q$ was flux,$\Delta E_{\mathrm{a}}$ was activation energy for permeation, $R$ was gas constant, and $T$ was absolute 


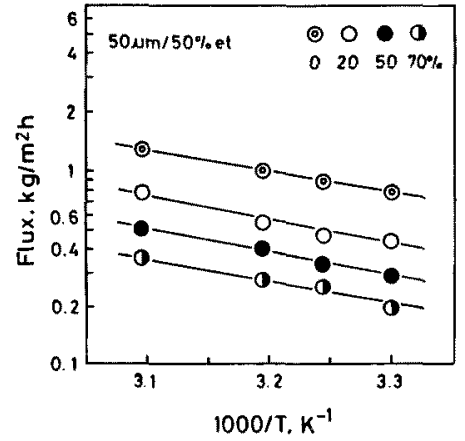

Fig. 7. Arrhenius plots of flux of the $0,20,50$ and $70 \%$ ethanol feeds through the $50 \mu \mathrm{m}$ thickness fibroin membrane treated in $50 \%$ ethanol.

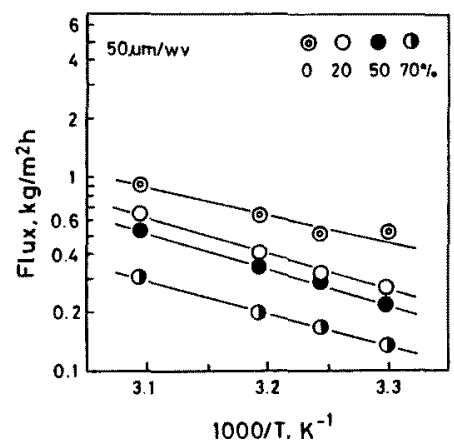

Fig. 8. Arthenius plots of flux of the $0,20,50$ and $70 \%$ ethanol feeds through the $50 \mu \mathrm{m}$ thickness fibroin membrane treated in saturated water vapor.

temperature. Since the number of experiments were restricted, deviation of the values was inevitable. The approximate energies obtained were as follows; 4.9, 5.2, 5.4 and $5.1 \mathrm{kcal} / \mathrm{mole}$ respectively for the feeds with $0,20,50$ and $70 \%$ ethanol in the ethanol-treated membrane, and $6.3,8.2,8.5$ and $7.6 \mathrm{kcal} / \mathrm{mole}$ in the water vapor treated membrane. Thus the energy for permeation was somewhat larger in the latter membrane. Minoura et al. have shown in the study of oxygen permeation that the permeation rate was reversely related with the activation energy, namely, the activation energy for permeation of oxygen was larger when permeation rate was smaller, and vice versa, for the silk fibroin membranes treated with methanol under various treatment time conditions $^{4}$. The same is true for pervaporation of water-ethanol. A membranes treated in $50 \%$

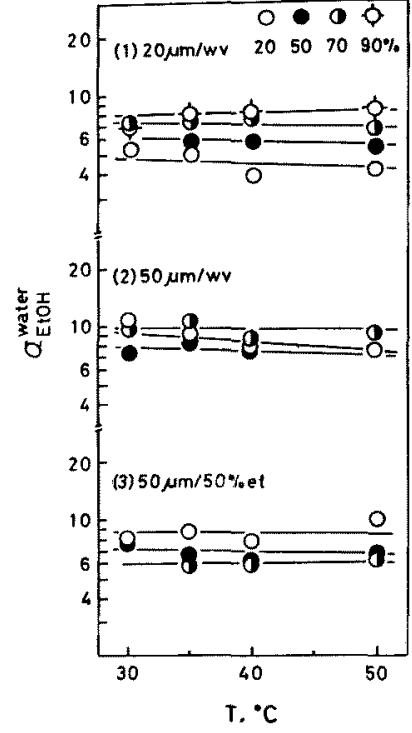

Fig. 9. Temperature dependences of separation factor of water for the $20 \mu \mathrm{m}$-thickness membrane treated with saturated water (1), and the $50 \mu \mathrm{m}$-thickness membranes treated with water vapor (2) and $50 \%$ ethanol (3).

ethanol which had lower activation energies showed the higher flux generally.

Figure 9 shows the dependence of separation factor on temperature for pervaporation. It should be pointed out that the values were slightly larger in the lower temperature range, and that was related to the lower permeation rates in the range.

\section{Conclusion}

It was found that silk fibroin membranes which were made insoluble by the treatments with saturated water vapor or with aqueous ethanol were water-permselective from water-ethanol mixtures by pervaporation. Higher permselectivity was performed with the membranes treated in water vapor in general, and the selectivity seemed to be dependent on the physical structure arised from the treatments. Permseparation became effective with the membranes of the thickness more than $20 \mu \mathrm{m}$, and for the more effective permseparation 50 micron was necessary. Activation energy for permeation was between $5 \mathrm{kcall}$ mole and $8 \mathrm{kcal} / \mathrm{mole}$, and the temperature dependence of permselectivity of water was slight. Both flux and separation factor must be improved 
simultaneously for the truly good permselective membranes, and therefore, further investigation is necessary to increase the two factors through making a careful study of the relations between the permseparation and the membrane structure by the treatments.

\section{References}

1) N. Hojo Eds., "Zoku Kenshi no Kozo (Structure of Silk Fiber)", Shinshu Univ., (1980), etc.

2) T. Asakura, "Sentan Kagaku Gijutsu Ten Shiryoshu", Tokyo Univ. of Agriculture and
Technology, p. 12, (1986)

3) H. Ishikawa and M. Nagura, Sen-i Gakkaishi (Sen-i to Kogyo), 39, P-353 (1983)

4) N. Minoura, M. Tsukada and M. Nagura, "3rd Membrane Symposium Preprint", (1987) 59.

5) T. Hirotsu, K. Mizoguchi, Y. Suda, S. Nakajima and A. Kitamura, Text. Res. J., in press.

6) S. Yamada, Maku, 6, 168 (1981)

7) T. Miyazawa, Kagaku to Kogyo, 15, 137 (1962)

8) K. Hirabayashi, p. 225 in ref. 1).

9) A. Kitamura, Nippon Sanshigaku Zasshi, 36, $113(1967)$

$$
\begin{aligned}
& \text { 綟フィブロイン膜を用いてのパーベーパレーションによる } \\
& \text { 水ーエタノール分離 }
\end{aligned}
$$

\begin{tabular}{|c|c|c|}
\hline 子材料研究所 & 広津敏博 & \\
\hline 東京都立紻維工業試験場 & 工東分場 & 中島 茂 \\
\hline 東京農工大学 & 北村受夫 & \\
\hline 縕維高分子材料研究所 & 漊口健作, & 的 \\
\hline
\end{tabular}

水蒸気中およびエタノール中で不溶化を図った絹フィ ブロイン膜を用いてパーベーパレーション法により水一 エタノール分離について検討を加えた。これらの膜は水 を選択的に透過した。その選択性は膜の厚さ，不溶化の 方法などに依存した。すなわち，膜厚 $20 \mu \mathrm{m}$ 程度より水 の選択透過があらわれ，厚さとと6に選択性が增加し透
過速度が減少した。また, 水蒸気処理による不溶化が選 択性向上のためにより有効であった。アレニウスプロッ トから求めた透過の活性化エネルギーは， 5-8 kcal/ moleであった。また，分離保数は高温側で幾分低下した。 しかしその程度は小さく，乙れは高い透過速度之相関す るあのである。 